\title{
Long Non-Coding RNA H19 Protects H9c2 Cells against Hypoxia-Induced Injury $\mathrm{Y}$ Targeting MicroRNA-139
}

\author{
Li-Cheng Gong $^{\mathrm{a}}$ Hai-Ming Xua Gong-Liang Guo ${ }^{\mathrm{a}}$ Tao Zhang ${ }^{\mathrm{b}}$ \\ Hong Changa
}

aDepartment of Cardiovascular Internal Medicine, bepartment of 'Department of Clinical Laboratory, China-Japan Union Hospital

\section{Key Words}

Long non-coding RNA H19 • Acute myocardial

- MAPK

\section{Abstract}

Background/Aims: Acute myocardial heart is diminished (ischemia) for long present study evaluated the effects o and mouse HL-1 cells. Meth migration and invasion, and respectively. $\mathrm{H} 19$ expressi the effects of non-phys $\mathrm{H} 19$ silence, and abnorr interacted miRNA $-\mathrm{H} 1$, gically expressed $\mathrm{H} 19$, knockdown of miR-139 with or without ypa was confirmed by measuring cell viability, ne nemia is primarily caused due to hypoxia. The The involved si of $\mathrm{HL}-1$ cells of cell vialo Knockd

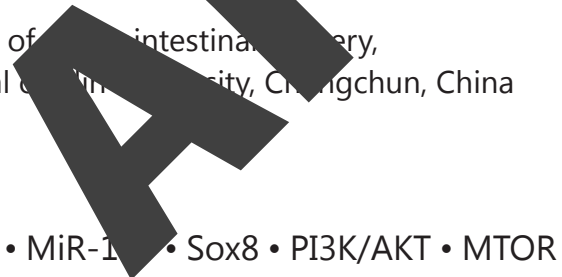
exp sed Sox8 on hypoxia-induced H9c2 cells. Moreover, the unstream target gene were virtually screened and verified. promoted contractility of $\mathrm{HL}-1$ cells. Conclusion: These findings suggest that $\mathrm{H} 19$ tes hypoxia-induced myocardial cell injury by miR-139-mediated up-regulation of Sox8, $g$ with activation of the PI3K/AKT/mTOR pathway and MAPK.

\section{Introduction}

Acute myocardial infarction (AMI) is one of the most severe manifestations of coronary artery diseases that causes irreversible damage to the heart muscle, and can lead to 


\section{Cellular Physiology \begin{tabular}{l|l|l} 
and Biochemistry 10.1159/000485354 & $\begin{array}{l}\text { (c) 2017 The Author(s). Published by S. Karger AG, Basel } \\
\text { www.karger.com/cpb }\end{array}$
\end{tabular} \\ Gong et al.: Role of LncRNA H19 in Hypoxia-Induced Myocardial Injury}

development of heart failure [1, 2]. AMI leads to more than 4 million deaths in Europe and northern Asia [3]. AMI is traditionally divided into ST elevation and non-ST elevation myocardial infarction (MI) [4]. Generally, MI occurs due to prolonged ischemic condition (diminished blood supply to the heart). Myocardial ischemia occurs due to increased myocardial metabolic demand, and/or decreased delivery of oxygen (hypoxia) and nutriep to the myocardium via the coronary circulation [5]. Therefore, the regulation of hypoxia induced injury to the myocardium and the underlying molecular mechanism are of grea importance.

Long non-coding RNAs (lncRNAs) are a diverse class of non-protein-codina-transc which play important roles in various biological processes [6, 7]. These biolog regulated by lncRNAs include invasion, metastasis, apoptosis, DNA damage, an microRNA (miR/miRNA) silencing, embryonic development, cardiac development [8-11]. Recently, few literatures have focused on the role of ln instance, circulating level of IncRNA ZFAS1 in AMI subjects was significa in non-AMI subjects, whereas the level of lncRNA CDR1AS in AMI subid that in non-AMI subjects [12]. Vausort et al. studied expressions of $\mathrm{n}$

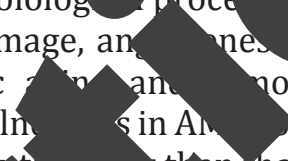
patients with MI, and showed that several IncRNAs were al atly exp $\quad$ in MI patients [13]. Another study also stated that IncRNA UCA1 pron apoptosis by inhibiting p27 expression [14].

The IncRNA H19, a $2.3 \mathrm{~kb}$ IncRNA transcribed from th in several tissues of fetus, but the expression cignificantl uced after birth $[15,16]$. Researchers have reported contradictory fun of $\mathrm{H} 19$, c cially in cancer $[15,17$ 20]. Initially, H19 is identified as a tumor suppr 1], however, mounting studies have reported that $\mathrm{H} 19$ is overexpressed in multi typ cancers, including breast cancer [17], bladder cancer [18], and cervical carcin 19 ole of H19 in cell injury has been evaluated in very few studies, for insta eported that H19 is re-expressed in rat vascular smooth muscle cells aft aly 20]. 10 our knowledge, very little is known about the functional roles of $\mathrm{H} 19$ in $\mathrm{y}$ to myocardial cells. Here, we studied the expression of $\mathrm{H} 19$ in hypoxic 2 cells. In addition, we studied the functions and the possible underlying ular numenanisms of H19 in hypoxic H9c2 cells. Besides, the effects of abnormally yre $\quad 9$ on contractility of mouse HL-1 cells were also investigated.

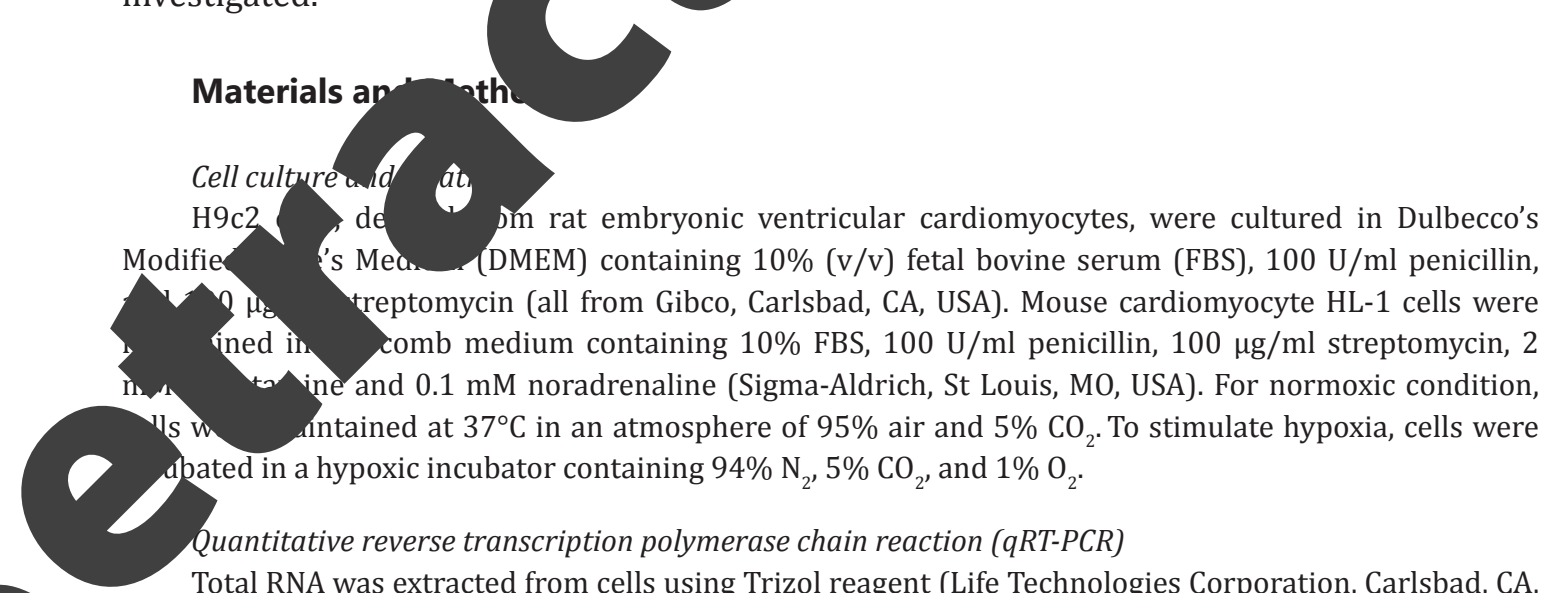

Total RNA was extracted from cells using Trizol reagent (Life Technologies Corporation, Carlsbad, CA, USA) according to the manufacturer's instructions. The expression level of H19 was measured by using One Step SYBR ${ }^{\circledR}$ PrimeScript ${ }^{\circledR}$ PLUS RT-RNA PCR Kit (TaKaRa Biotechnology, Dalian, China). For the measurement of miR-139 expression, TaqMan MicroRNA Reverse Transcription Kit and TaqMan Universal Master Mix II were used for reverse transcription and quantitative PCR. For the measurement of mRNA expression level of Sox8, RNA PCR Kit (AMV) Ver. 3.0 and SYBR ${ }^{\circledR}$ Premix Ex Taq ${ }^{\mathrm{TM}}$ (both TaKaRa Biotechnology) were used for reverse transcription and quantitative PCR. The relative expression was normalized to glyceraldehyde3-phosphate dehydrogenase (GAPDH; for H19 or Sox8 mRNA) or U6 (for miR-139) using the $2^{-\Delta \Delta \mathrm{Ct}}$ cycle threshold method [22].

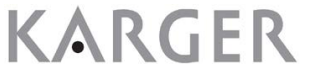




\section{Cellular Physiology Cell Physiol Biochem 2017;44:857-869

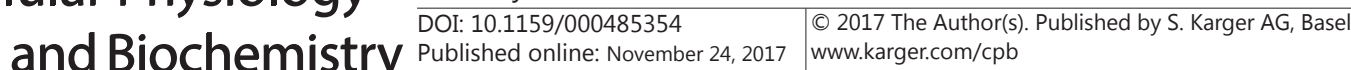 and Biochemistry

Cell transfection

Short-hairpin (sh) RNAs directed against H19 or Sox8, or non-targeting sequence was ligated into the U6/GFP/Neo plasmids (GenePharma, Shanghai, China) and the resultant plasmids were referred to as sh-H19, sh-Sox8 or shNC. Full-length H19 sequences and Sox8 sequences were sub-cloned into pcDNA3.1 (Invitrogen, Carlsbad, CA, USA) and pEX-2 plasmids (GenePharma), respectively, and the resultant plasmi were referred to as pc-H19 and pEX-Sox8. Lipofectamine 3000 reagent (Life Technologies Corporation) wc used for cell transfection according to the manufacturer's instructions. The stably transfected cells were selected by the culture medium containing $0.5 \mathrm{mg} / \mathrm{ml}$ G418 (Sigma-Aldrich). Scramble miRs, miR mimic, miR-139 inhibitor and its negative control (NC), synthesized by Life Technologies Cornoration, transfected into cells using Lipofectamine 3000 reagent and the transfected cells were $\mathrm{h}$ post-transfection.

Cell viability, migration and invasion assays

Cell viability was assessed by using 3-(4, 5-dimethylthiazol-2-yl)-2, 5-diphen (MTT) assay. In brief, cells $\left(1 \times 10^{5}\right.$ cells/well) were seeded into 96-well plates and treatments, $20 \mu \mathrm{l}$ MTT solution ( $5 \mathrm{mg} / \mathrm{ml}$; Sigma-Aldrich) was added into each $w$ $\mathrm{h}$ post-hypoxia, and the mixture was incubated at $37^{\circ} \mathrm{C}$ for additional ${ }^{\mathrm{h}}$. After ac of $100 \mu \mathrm{l}$ dimethyl sulfoxide, absorbance was read using a Microplate reader (Bio-rad $\quad$ CA, USA, $>\mathrm{nm}$.

Cell migration was determined using a modified two-chambe gra wrth a pore size of 8 $\mu \mathrm{m}$. Cells suspended in $200 \mu \mathrm{l}$ of serum-free medium were seeded Transwell culture chamber, and $600 \mu \mathrm{l}$ of complete $\mathrm{m}^{\wedge} \mathrm{ium}$ was add the lower compartment. After incubation at $37^{\circ} \mathrm{C}$, cells were fixed with methanol. raversed ce removed from the upper surface of the filter carefully with a cotton swab. Traverse on the low er side of the filter were stained with crystal violet and counted. The protocol of cell on consistent with that of cell migration except that the membranes were pre-coated with Ma I (BD) ences, San Jose, CA, USA).

\section{Apoptosis assay}

Cell apoptosis analysis was performe aSI copidıum iodide (PI) and fluorescein isothiocynate (FITC)-conjugated Annexin V staining, Br re washed in phosphate buffered saline (PBS), suspended in binding buffer, and $\quad$-Annexin $\mathrm{V}$ in the presence of $50 \mu \mathrm{g} / \mathrm{ml} \mathrm{RNase} \mathrm{A}$ (Sigma-Aldrich) according to the cturers instructions. Flow cytometry analysis was done using a FACScan (Beckman Coulter, Fy ton, Data were analyzed using FlowJo software (Tree Star, San
Carlos, CA, USA).

\section{Luciferase reporter ass}

The fragment 8 slated region (3'UTR) containing the predicted miR-139 binding site was cloned into ror (Promega, Madison, WI, USA) to form the reporter vector Sox8-wild-type (Sox8-Wt). T mulat a de binding site of miR-139 in Sox8 3'UTR, site-mutations were performed to generato pe (Sox8-Mt). Then the vectors (Sox8-Wt or Sox8-Mt) and miR-139 mimics or scrambr were co transfected into cells, and Dual Luciferase Reporter Assay System (Promega) was tes ciferase activity.

\section{ter blot analysis}

eins used for western blotting were extracted using RIPA lysis buffer (Beyotime Biotechnology,

Aghai, China) and were quantified using $\mathrm{BCA}^{\mathrm{TM}}$ Protein Assay Kit (Pierce, Appleton, WI, USA). After tion using SDS-PAGE, proteins in the gels were transferred into polyvinylidene difluoride (PVDF) branes. Then, membranes were blocked with non-fat milk and incubated with primary antibody at $4^{\circ} \mathrm{C}$ overnight, followed by wash and incubation with secondary antibody marked by horseradish peroxidase for $1 \mathrm{~h}$ at room temperature. After rinsing, the membranes were transferred into Bio-Rad ChemiDoc ${ }^{\mathrm{TM}} \mathrm{XRS}$ system, and then $200 \mu \mathrm{l}$ Immobilon Western Chemiluminescent HRP Substrate (Millipore, Billerica, MA, USA) was added to cover the membrane surface. The signals were captured using Image Lab ${ }^{\mathrm{TM}}$ software (Bio-Rad).

\section{Statistical analysis}

The results of multiple experiments are presented as mean \pm standard deviation (SD). Statistical analyses were performed on normalized data using Graphpad 6.0 statistical software. P values were 


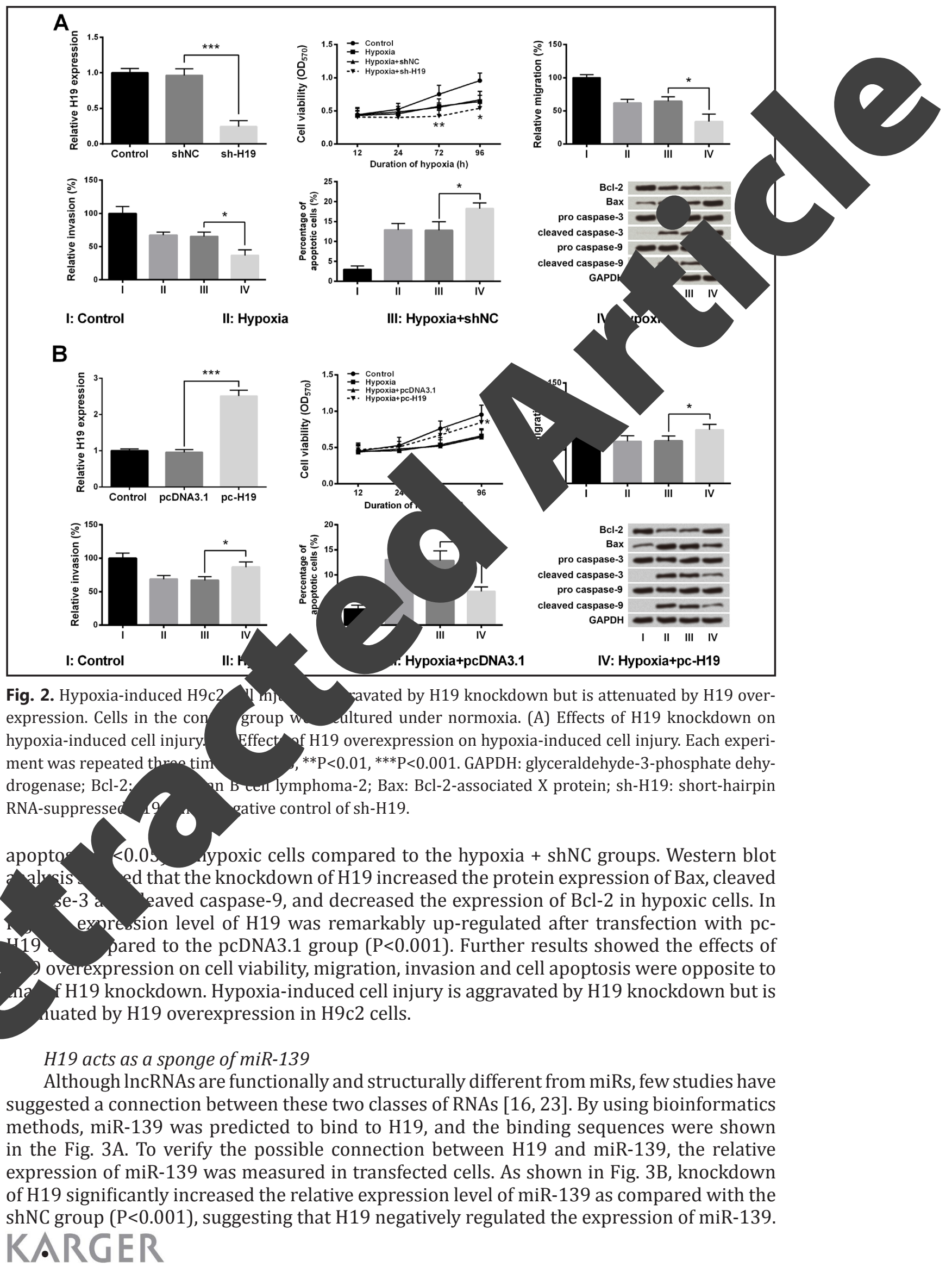




\section{Cellular Physiology and Biochemistry Publisnect $\begin{aligned} & \text { DOI: 10.1159/000485354 } 2017 \text { The Author(s). Published by S. Karger AG, Basel } \\ & \text { www.karger.com/cpb }\end{aligned}$

Results indicate that $\mathrm{H} 19$ can act as a sponge for miR-139.

The effects of H19 knockdown on hypoxia-induced cell injury are reversed by miR-139 suppression

As miR-139 was identified as a target of H19, we studied the effects of miR-139 on hypoxia-induced cell injury with or without H19 knockdown. After cell transfection, expression level of miR-139 was significantly up-regulated by miR-139 mimic as compared to the scramble group $(\mathrm{P}<0.001$; Fig. $4 \mathrm{~A})$ but was markedly down-regulated by miR139 inhibitor as compared to the NC group $(\mathrm{P}<0.001$; Fig. $4 \mathrm{~B})$. Then, the effects of abnormally expressed miR139 on cell viability, migration, invasion, and apoptosis of hypoxia-treated H9c2 cells were explored. When compared to the hypoxia + NC groups, miR-139 inhibition significantly increased cell viability (both $\mathrm{P}<0.05$ at $72 \mathrm{~h}$ and 96 h post-hypoxia; Fig. 4C), migration $(\mathrm{P}<0.05$; Fig. 4D) and invasion $(\mathrm{P}<0.05$. Fig. 4E) but reduced cell apoptosis (P apoptosis-associated proteins was $\mathrm{re}$ the effects of miR-139 inhibi further explored. As compar both miR-139 and H19 exp ssio and 96 h post-hypoxia; $\mathrm{F}$ decreased cell apoptosi $(\mathrm{H})$, mig on $(\mathrm{P}<0.01$; Fig. $4 \mathrm{I})$ and invasion $(\mathrm{P}<0.01$; Fig. $4 \mathrm{~J})$, but $<0.0^{\circ}$ Fig. 4K). Likewise, H19 knockdown-induced alterations of apoptosis-associnted were all reversed by miR-139 inhibition (Fig. 4L). These findings sugge 9 krockdown aggravates hypoxia-induced cell injury through upregulating $\mathrm{mil}$

Soy egat egulated by miR-139

the online TargetScan software, possible target genes of miR-139 were virtually red. those targets, we chose Sox8 to deeply investigate. The binding sequences miR 39 and Sox8 3'UTR were shown in the Fig. 5A. The qRT-PCR and western showed that miR-139 mimic significantly decreased the mRNA and protein ressions of Sox8 $(\mathrm{P}<0.01$; Fig. 5B) while miR-139 inhibitor increased the expression
$\mathrm{x} 8(\mathrm{P}<0.001$; Fig. 5C), indicating that Sox8 was negatively regulated by miR-139 ession. Dual luciferase reporter assay was performed to verify the targeting between 1R-139 and Sox8 3'UTR. As shown in Fig. 5D, luciferase activity was significantly decreased in cells co-transfected with miR-139 mimic and Sox8-Wt, as compared to the co-transfection with Sox8-Wt and scramble miRs $(\mathrm{P}<0.05)$. No significant changes were observed in cells co-transfected with Sox8-Mt vector. These findings suggest that Sox8 is a target of miR-139.

Overexpression of Sox8 alleviates hypoxia-induced cell injury of H9c2 cells

After stable transfection, the qRT-PCR and western blot results showed that pEX-Sox8 significantly increased the mRNA and protein expressions of Sox8 $(\mathrm{P}<0.001$; Fig. 6A-6B), while sh-Sox8 significantly decreased the expression of Sox8 ( $\mathrm{P}<0.001$; Fig. 6C-D). In further 
A

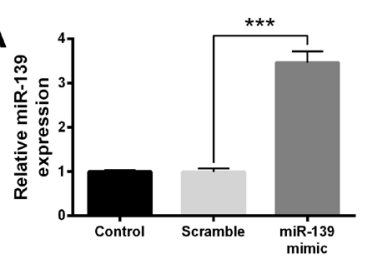

D

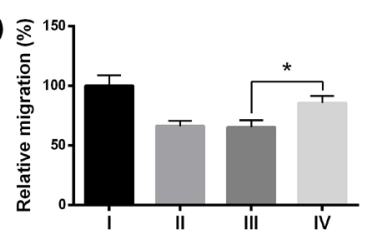

G

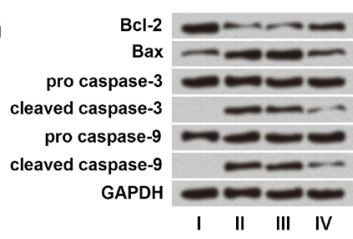

J

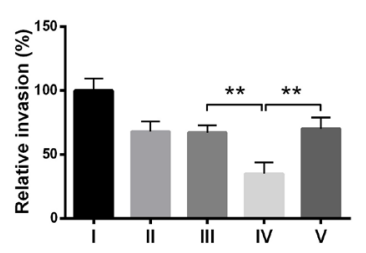

B

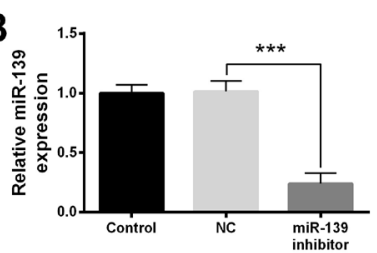

E ร

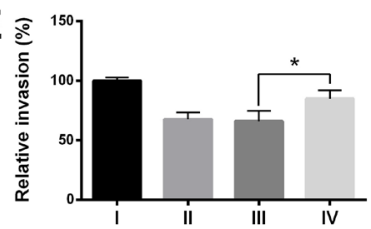

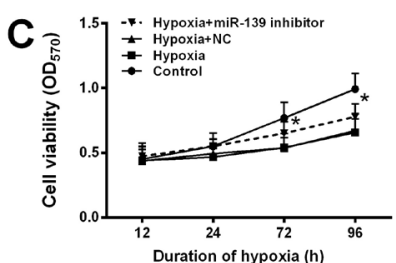

$\mathbf{F}$

$F$

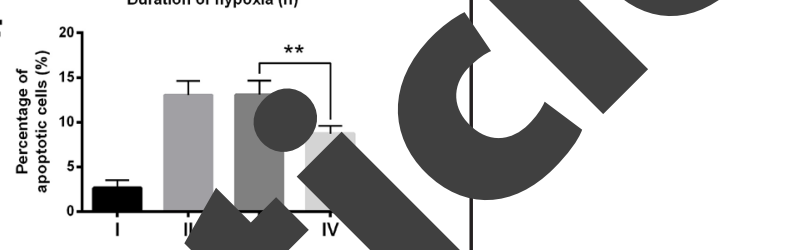

H ${ }^{1.5} \because$ Hypoxia+sh-H19+miR-139 inhibitor

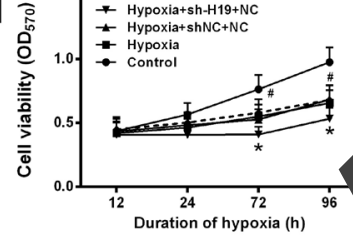

K
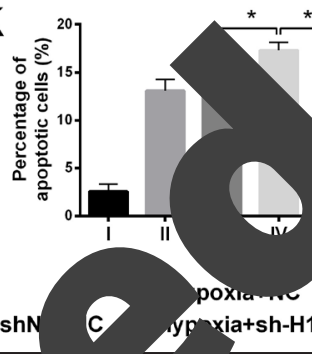

C Poxiant IV: Hypoxia+miR-139 inhibitor

H-L I: Control II: Hypoxia III: Hypoxia+sh

Fig. 4. H19 knockdown aggravat control group were cultured und qRT-PCR. Effects of miR-139j expressions of apoptosis-as miR-139 inhibition on cell $y$ sis-associated protein $-\mathrm{Y}$ in

ated pro

ated $\mathrm{p}$ a. $\checkmark$

injury through up-regulating miR-139. Cells in the oxia, (A-B) Relative miR-139 expression was measured by using

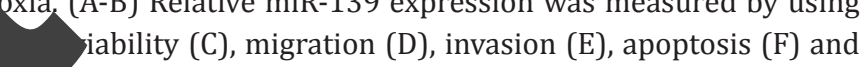
$(G)$ in hypoxia-treated H9c2 cells were measured. Effects of yigration (I), invasion (J), apoptosis (K) and expressions of apoptowith H19 knockdown under hypoxia were measured. Each experiment was repeate between the hyp and the hypoxia + miR-139 inhibitor group. In $\mathrm{H},{ }^{*}$ indicates significance of comparison wee puxia + sh-H19 + NC group and the hypoxia + shNC $+\mathrm{NC}$ group, and \# indicates significa compa between the hypoxia + sh-H19 + miR-139 inhibitor group and the hypoxia + sh\# $<$ 0.05. GAPDH: glyceraldehyde-3-phosphate dehydrogenase; Bcl-2: mammalian B cell oma-2, $\mathrm{cl}$-2-associated X protein; sh-H19: short-hairpin RNA-suppressed H19; shNC: negative

priments, effects of abnormally expressed Sox8 on cell viability, migration, invasion, and tosis of the hypoxic H9c2 cellswere explored. Theresults showed thatSox8 overexpression shificantly increased cell viability (both $\mathrm{P}<0.05$ at $72 \mathrm{~h}$ and $96 \mathrm{~h}$ post-transfection; Fig. 6E), migration $(\mathrm{P}<0.05$; Fig. 6F), and invasion $(\mathrm{P}<0.05$; Fig. 6G); and decreased cell apoptosis $(\mathrm{P}<0.05$; Fig. $6 \mathrm{H})$ as compared to the hypoxia + pEX-2 groups. Western blot results showed the decreased expression of Bcl-2 and the increased expressions of pro-apoptotic proteins, which were induced by hypoxia, were all reversed by Sox8 overexpression (Fig. 6I). However, the effects of Sox8 silence on hypoxia-treated cells were just the opposite. These findings suggest that overexpression of Sox8 alleviates hypoxia-induced cell injury of H9c2 cells. 
Fig. 5. Sox8 is a target of miR139. (A) Sequence complementarity between Sox8 3'-untranslated region (3'UTR) and miR-139-5p. (B-C) mRNA and protein expressions of Sox8 in transfected H9c2 cells. (D) Relative luciferase activity of H9c2 cells co-transfected with Sox8-wild-type (Sox8-Wt) or Sox8-mutated-type (Sox8-Mt) vectors and scramble miRNAs or miR-139 mimic. Each experiment was repeated three times. ${ }^{*} \mathrm{P}<0.05$, ${ }^{*} \mathrm{P}<0.01, \quad{ }^{* * *} \mathrm{P}<0.001$. GAPDH: glyceraldehyde-3-phosphate dehydrogenase; NC: negative control of miR-139 inhibitor.

A

Sox8 3'UTR

Rat (791-796) $\quad 5^{\prime}$...uguccCUGGAGgccucc... 3'

Mouse (773-778) $5^{\prime}$...uguccCUGGAGgccucc... $3^{\prime}$ Human (834-839) 5 '...ccgccCUGGAGggcccg... 3'

$$
\|||||
$$

Human miR-139-5p 3' uGACCUCugugca... 5' Rat (mouse) miR-139-5p 3' GACCUCugugca... 5'
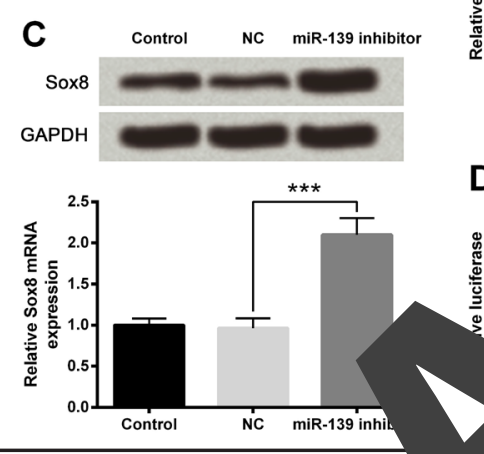
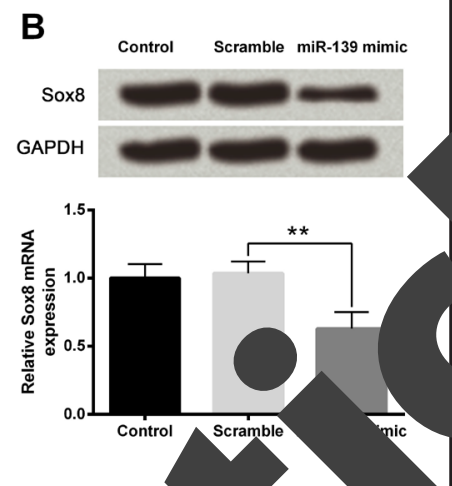
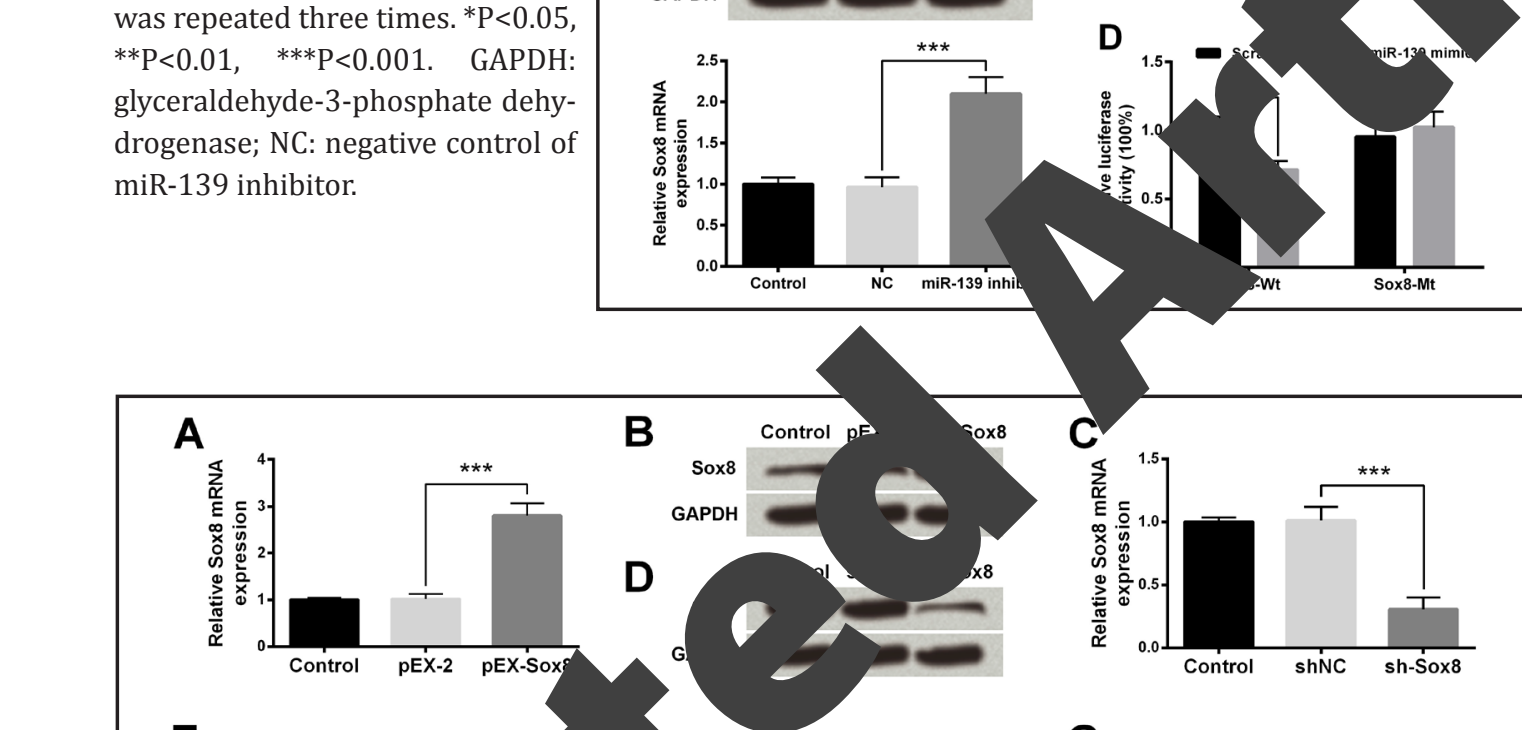

E

B
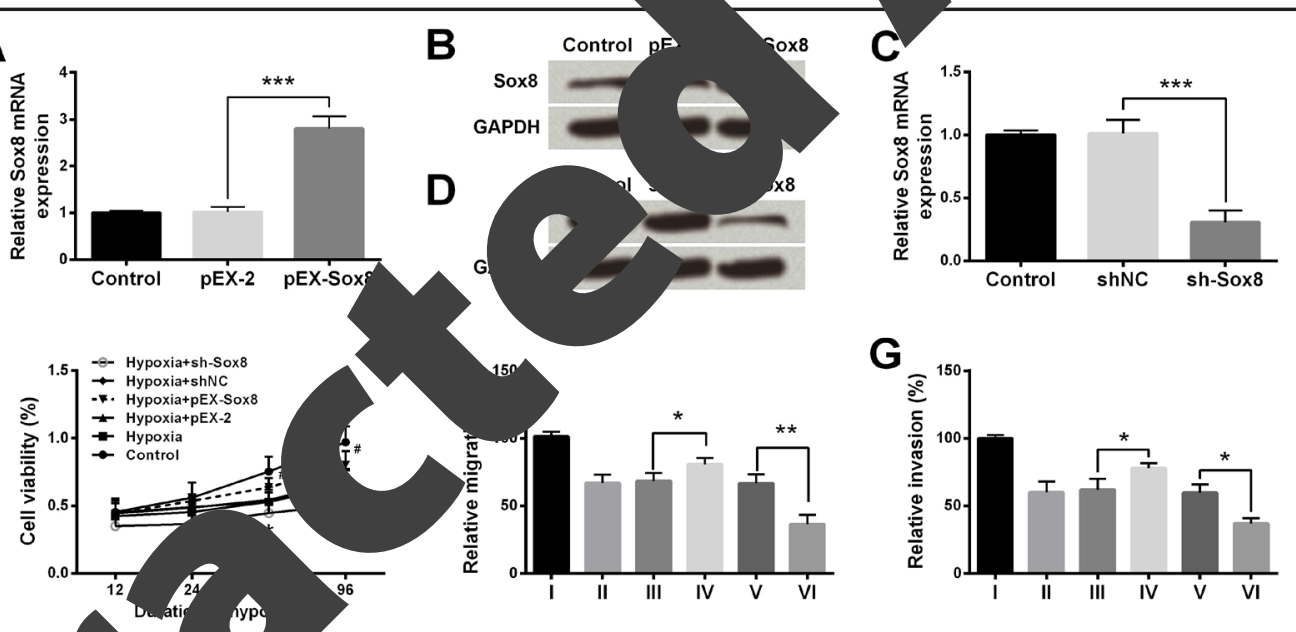

6. Overexpression of Sox8 alleviates hypoxia-induced H9c2 cell injury. Cells in the control group were cultured under normoxia. qRT-PCR was used to measure mRNA expression and western blot was used to measure protein expression of Sox8 in transfected H9c2 cells (A-D). (E) Cell viability, (F) migration, (G) invasion, and (H) apoptosis of H9c2 cells were estimated. (I) Western blot analysis was used to measure the expressions of apoptosis-associated proteins. Each experiment was repeated three times. ${ }^{*} \mathrm{P}<0.05,{ }^{* *} \mathrm{P}<0.01$, $* * * \mathrm{P}<0.001$. In $\mathrm{E}, *$ indicates significance of comparisons compared with the hypoxia + shNC group, and \# indicates significance of comparison compared with the hypoxia + pEX-2 group, \#P<0.05. GAPDH: glyceraldehyde-3-phosphate dehydrogenase; Bcl-2: mammalian B cell lymphoma-2; Bax: Bcl-2-associated X protein; sh-Sox8: short-hairpin RNA-suppressed Sox8; shNC: negative control of sh-Sox8. 


\section{Cellular Physiology and Biochemistry

Sox8 activates the phosphoinositide 3-kinase (PI3K)/ serine-threonine kinase (AKT)/ mechanistic target of rapamycin (mTOR) pathway and mitogenactivated protein kinase (MAPK)

We then studied the underlying mechanism for the H19-asssociated modulations using western blot analysis. The results showed that overexpression of Sox8 increased the expressions of phosphorylated PI3K, AKT, mTOR, and MAPK, while the effects of Sox8 inhibition were just the opposite (Fig. 7). These findings indicate that overexpression of Sox8 may alleviate hypoxia-induced cell injury by activating the $\mathrm{PI} 3 \mathrm{~K} / \mathrm{AKT} / \mathrm{mTOR}$ pathway and MAPK.

H19 overexpression up-regulates expression of sarcoplasmic reticulum $\mathrm{Ca}^{2+}$ ATPase (SERCA2a) in HL-1 cells

Considering the interaction between H19 and miR-139 as well as the interaction between miR-139 and Sox8 are existed in mice, which are shown in the Fig. $3 \mathrm{~A}$ and Fig. $5 \mathrm{~A}$, we finally explored the effects of abnormally expressed $\mathrm{H} 19$ on contractility mouse HL-1 cells. Interestingly, prote pression level of SERCA2a was redu hypoxia and further reduced (Fig. 8A), whereas the downreversed by H19 overexp sol. Results suggest that $\mathrm{H} 19$ omotes ractility. The final regulato ircui of H19 in hypoxia-induced collin shown in Fig. 9.

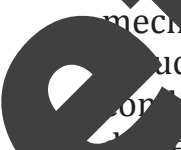
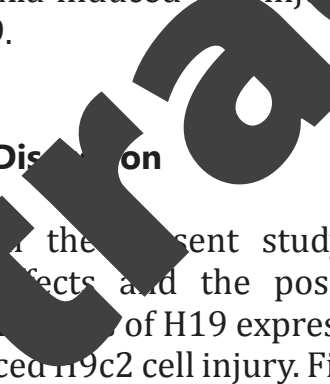

easing cell viability, migration and vasion, and increasing apoptosis as well as up-regulation of H19. Subsequently, hypoxia-induced cell injury was aggravated by H19 knockdown but was attenuated by H19 overexpression. In further experiments, H19 was identified as a sponge for miR-139. Interestingly, the effects of H19 knockdown on the hypoxic cells were reversed by miR139 suppression. Sox8 was revealed to be KARGER

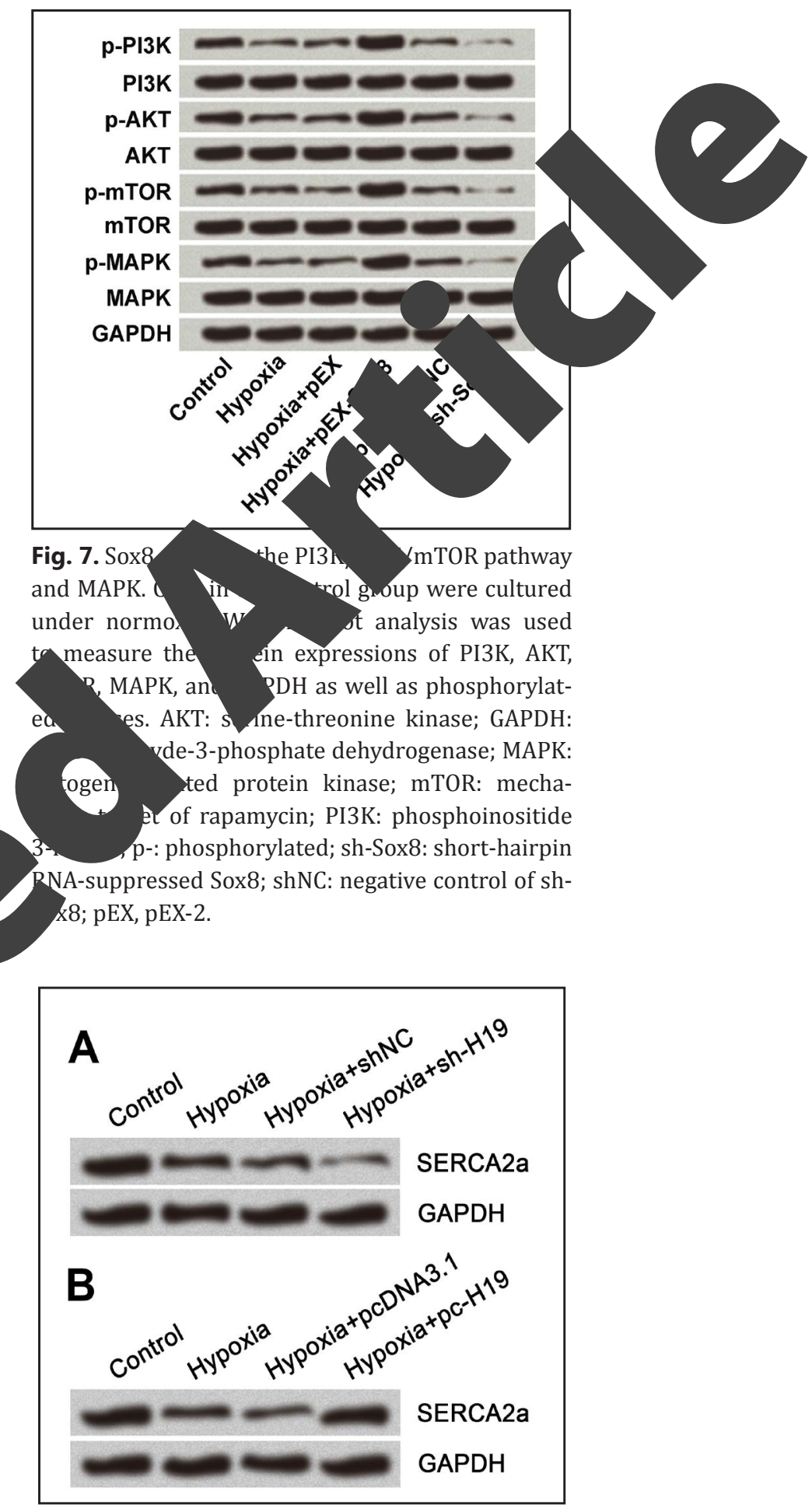

Fig. 8. H19 promotes contractility of HL-1 cells. Cells in the control group were cultured under normoxia. (A-B) Western blot analysis was used to measure the protein expressions of sarcoplasmic reticulum $\mathrm{Ca}^{2+}$ ATPase (SERCA2a). GAPDH: glyceraldehyde-3-phosphate dehydrogenase; sh-H19: short-hairpin RNAsuppressed H19; shNC: negative control of sh-H19. 


\section{Cellular Physiology and Biochemistry

Fig. 9. Regulatory circuit. Solid arrows indicated positive regulation but dotted indicated negative regulation. AKT: serine-threonine kinase; MAPK: mitogen-activated protein kinase; mTOR: mechanistic target of rapamycin; PI3K: phosphoinositide 3-kinase; p: phosphate group.

a target of miR-139 and its

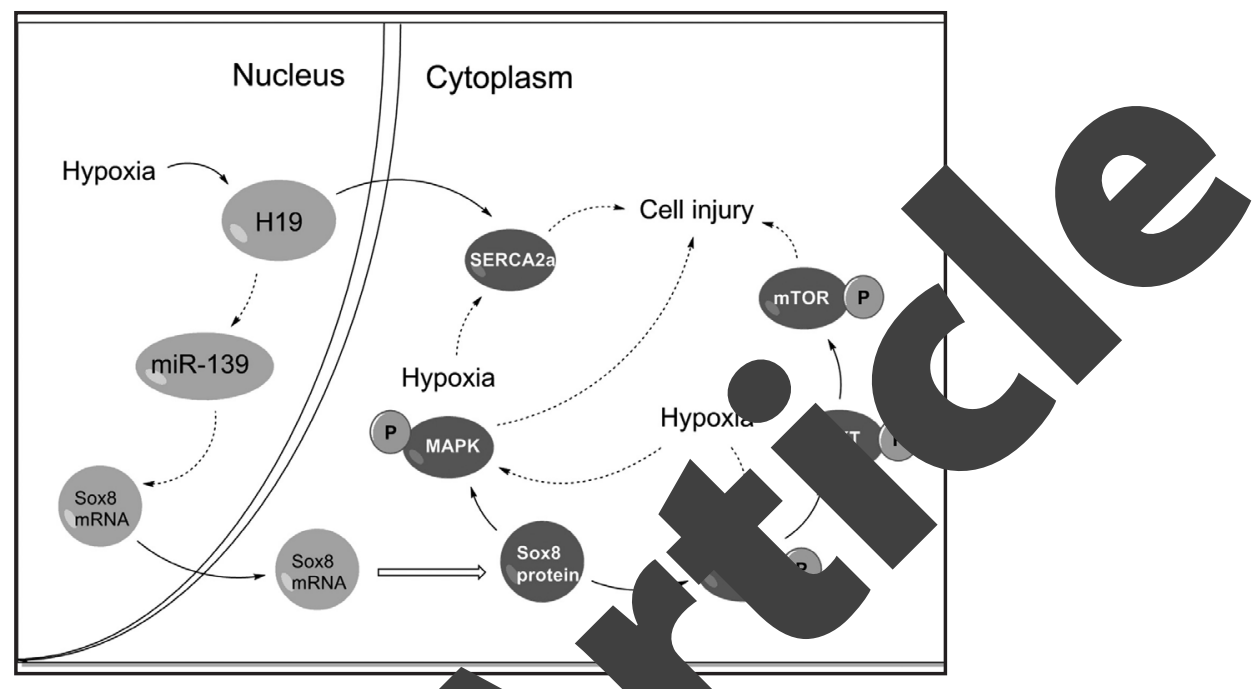
expression was negatively regulated by miR-139. Overexp to 8 de eased hypoxiainduced cell injury by activating the PI3K/AKT/mTOR path identified to promote contractility in HL-1 cells

Role of lncRNA H19 has been studied in s al. reported that $\mathrm{H} 19$ promotes proliferation of al. reported that $\mathrm{H} 19$ promotes proliferation of p atic ducta adenocarcinoma cells [24]. Yang et al. showed that overexpression of $\mathrm{H}_{1}$ cell proliferation and decreases apoptosis of gastric cancer cells [25]. In our st we nstrated that knockdown of H19 decrease cell viability, migration and invasion 3 apoptosis through mitochondrialand caspase-dependent pathways in hy 9 cells, whereas the effects of H19 overexpression were just the opposit
effects of H19 on hypoxia-injy ed $\mathrm{H} 9$

We found $\mathrm{H} 19$ silence $\mathrm{fl}$. markedly up-regulated after hypoxia-induced cell injy niRs all, non-coding RNAs that regulate the expression

ed t. ap-regulating miR-139. In our study, H19 was of protein-encoding ge at the post-transcriptional level. Accumulating evidence has reported the key roles

29]. A previous $\mathrm{s}^{+}$ neurons and ra H19 was preanty to $\mathrm{iRc}$ the process of hypoxia-induced myocardial injury [26ression of miR-139 was reported to be down-regulated in to miR-139-5p. Thus, we speculated that there might be an interactio tw and miR-139. Following results illustrated miR-139 was negatively regulat $\mathrm{H} 19$, a more data proved that the H19 inhibition aggravated hypoxia-induced p-regulating miR-139.

e the plored the possible underlying mechanism for the effects of miR-139 o. ${ }^{\wedge}$ oxic cells. Towards this goal, putative target genes of miR-139 were screened ing ormatics methods. Among those genes, Sox8, belonging to group E of SOX ilily proteins, is reported to promote cell proliferation of diverse cancer cells $[31,32]$. se al researchers have reported that Sox8 is expressed in the developing heart $[33,34]$. vever, Sox8 has not been studied in hypoxia-induced myocardial injury. In the present study, Sox8 was identified to be a target of miR-139. Meanwhile, overexpression of Sox8 decreased hypoxia-induced cell injury by increasing cell viability, migration, and invasion and decreasing apoptosis. In further experiments, we studied effects of Sox8 on the PI3K/ AKT/mTOR signal pathway and MAPK activation. PI3K/AKT signal pathway is an important pathway for protecting myocardial cells against hypoxia-induced injury [35, 36]. Xiao et al. reported that hydrogen sulfide protects myocardial cells against hypoxia-induced injury via mTOR activation [37]. Chen et al. reported that lipoxin A4-induced heme oxygenase-1 protects cardiomyocytes against hypoxia/reoxygenation injury via p38 MAPK activation

\section{KARGER}




\section{Cellular Physiology

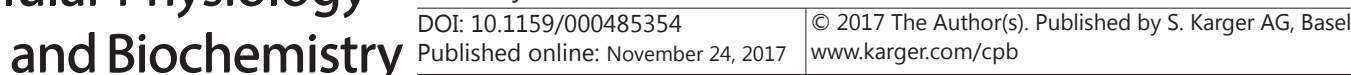

and Nrf2/ARE complex [38]. Our results showed that overexpression of Sox8 might alleviate hypoxia-induced H9c2 cell injury by activating the PI3K/AKT/mTOR pathway and MAPK, which should be verified by more experiments in the future.

HL-1 cells, established from the AT-1 mouse atrial cardiomyocyte tumor, are a widely used cell line which retains phenotypic characteristics of adult cardiomyocyte, such contractile phenotype [39]. SERCA2a acting as the ATP-dependent calcium pump is reporte to be a prime target for modulating cardiac contractility [40]. In our study, we finally explored the roles of non-physiologically expressed H19 in modulation of contractility by measur the protein expression of SERC2a. Results illustrated that hypoxia inhibited contractili HL-1 cells and the contractility was further inhibited by H19 knockdown. Co rely, overexpression could promote contractility, suggesting the potential protective in hypoxia-treated HL-1 cells.

\section{Conclusion}

In conclusion, this study demonstrated that knockd of H19 vates hypoxiainduced $\mathrm{H} 9 \mathrm{c} 2$ cell injury by decreasing cell viability, mig and increasing cell apoptosis. Importantly, we found that $\mathrm{H} 19$ acted as a s, ge $\quad 139$ and Sox8 was a target of miR-139. Furthermore, we found overexpression misut protect H9c2 cells from hypoxia-induced injury by activating the $P$ VAKT/mT athway and MAPK. Finally, $\mathrm{H} 19$ was identified to promote contractility in H lls. Our re rch is a preliminary study that might provide new insights in the preventionents should be done in other cell types of cardiomy tes rify the conclusions.

\footnotetext{
ar Heart J 2014;35:2950-2959.

$\Rightarrow$ Thygesen K, Alpert JS, Jaffe AS, Simoons ML, Chaitman BR, White HD, Katus HA, Lindahl B, Morrow DA, Thygesen K, Alpert JS, Jaffe AS, Simoons ML, Chaitman BR, White HD, Katus HA, Lindahl B, Morrow DA,
Ylemmensen PM, Johanson P, Hod H, Underwood R, Bax JJ, Bonow RO, Pinto F, Gibbons RJ, Fox KA, Atar D, Newby LK, Galvani M, Hamm CW, Uretsky BF, Steg PG, Wijns W, Bassand JP, Menasche P, Ravkilde J, Ohman EM, Antman EM, Wallentin LC, Armstrong PW, Simoons ML, Januzzi JL, Nieminen MS, Gheorghiade M, Filippatos G, Luepker RV, Fortmann SP, Rosamond WD, Levy D, Wood D, Smith SC, Hu D, Lopez-Sendon JL, Robertson RM, Weaver D, Tendera M, Bove AA, Parkhomenko AN, Vasilieva EJ, Mendis S: Third universal definition of myocardial infarction. Circulation 2012;126:2020-2035.

5 Nazir S, Tachamo N, Lohani S, Hingorani R, Poudel DR, Donato A: Acute myocardial infarction and antiphospholipid antibody syndrome: a systematic review. Coron Artery Dis 2017;28:332-335.

$\checkmark 6$ Ye LC, Zhu X, Qiu JJ, Xu J, Wei Y: Involvement of long non-coding RNA in colorectal cancer: From benchtop to bedside (Review). Oncol Lett 2015;9:1039-1045.
}

Disclosure Statement

References

$>1$ Roger VL, Go AS wavd-Jo

hjamin EJ, Berry JD, Borden WB, Bravata DM, Dai S, Ford ES, Fox CS,
Fullerton HJ, Lisabeth LK al scus GM, Marelli A, Matchar DB, Moy CS, Mozaffarian D, Mussolino ME, Nichol G, Payr NP, s Sorlie PD, Sotoodehnia N, Turan TN, Virani SS, Wong ND, Woo D, Turner MB: Sso Circulation 2012;125:188-197.

Eed G JE, Cannon CP: Acute myocardial infarction. Lancet 2017;389:197-210.

holsM, ownsend N, Scarborough P, Rayner M: Cardiovascular disease in Europe 2014: epidemiological 


\section{Cellular Physiology

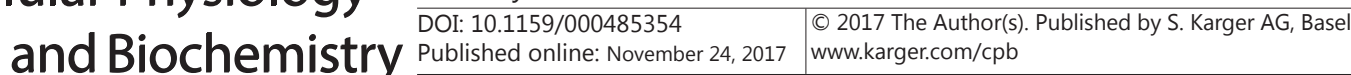

7 Gu M, Zheng A, Tu W, Zhao J, Li L, Li M, Han S, Hu X, Zhu J, Pan Y, Xu J, Yu Z: Circulating LncRNAs as Novel, Non-Invasive Biomarkers for Prenatal Detection of Fetal Congenital Heart Defects. Cell Physiol Biochem 2016;38:1459-1471.

8 Yang Z, Li X, Yang Y, He Z, Qu X, Zhang Y: Long noncoding RNAs in the progression, metastasis, and prognosis of osteosarcoma. Cell Death Dis 2016;7:e2389.

-9 Zhou X, Liu S, Cai G, Kong L, Zhang T, Ren Y, Wu Y, Mei M, Zhang L, Wang X: Long Non Coding RNA MALAT Promotes Tumor Growth and Metastasis by inducing Epithelial-Mesenchymal Transition in Oral Squamous Cell Carcinoma. Sci Rep 2015;5:15972.

10 Bouckenheimer J, Assou S, Riquier S, Hou C, Philippe N, Sansac C, Lavabre-Bertrand T, Commos T, Lem JM, Boureux A, De Vos J: Long non-coding RNAs in human early embryonic development af in ART. Hum Reprod Update 2016;23:19-40.

11 Wang H, Bei Y, Shi J, Xiao J, Kong X: Non-Coding RNAs in Cardiac Aging. Cell Physiol Bi 1687.

12 Zhang Y, Sun L, Xuan L, Pan Z, Li K, Liu S, Huang Y, Zhao X, Huang L, Wang Z, Hou Y, Liu Y, Gao F, Zhang Y, Wang S, Du Z, Lu Y, Yang B: Reciprocal Changes of Circulatino ZFAS1 and CDR1AS Predict Acute Myocardial Infarction. Sci Rep 2016;6:22384

13 Vausort M, Wagner DR, Devaux Y: Long noncoding RNAs in patient Res 2014;115:668-677.

14 Liu Y, Zhou D, Li G, Ming X, Tu Y, Tian J, Lu H, Yu B: Long non codin. cardiomyocyte apoptosis by suppression of p27 expression. Cell Phy Gabory A, Ripoche MA, Yoshimizu T, Dandolo L: T RNA. Cytogenet Genome Res 2006;113:188-193.

-16 Li H, Yu B, Li J, Su L, Yan M, Zhu Z, Liu B: Overexpressia metastasis of gastric cancer. Oncotarget 2014;5:23

17 Berteaux N, Lottin S, Monte D, Pinte S, Quatannen Adriaenssens E: H19 mRNA-like noncoding prost cancer cell proliferation through positive control by E2F1 J Biol Chem 200

18 Luo M, Li Z, Wang W, Zeng Y, Liu Z, Qiu by regulating ID2 expression,

19 Kim SJ, Park SE, Lee C, Lee SY, m JM, un.n: Alterations in promoter usage and expression levels of Biochim Biophys Acta 2

20 Kim DK, Zhang L, Dzau
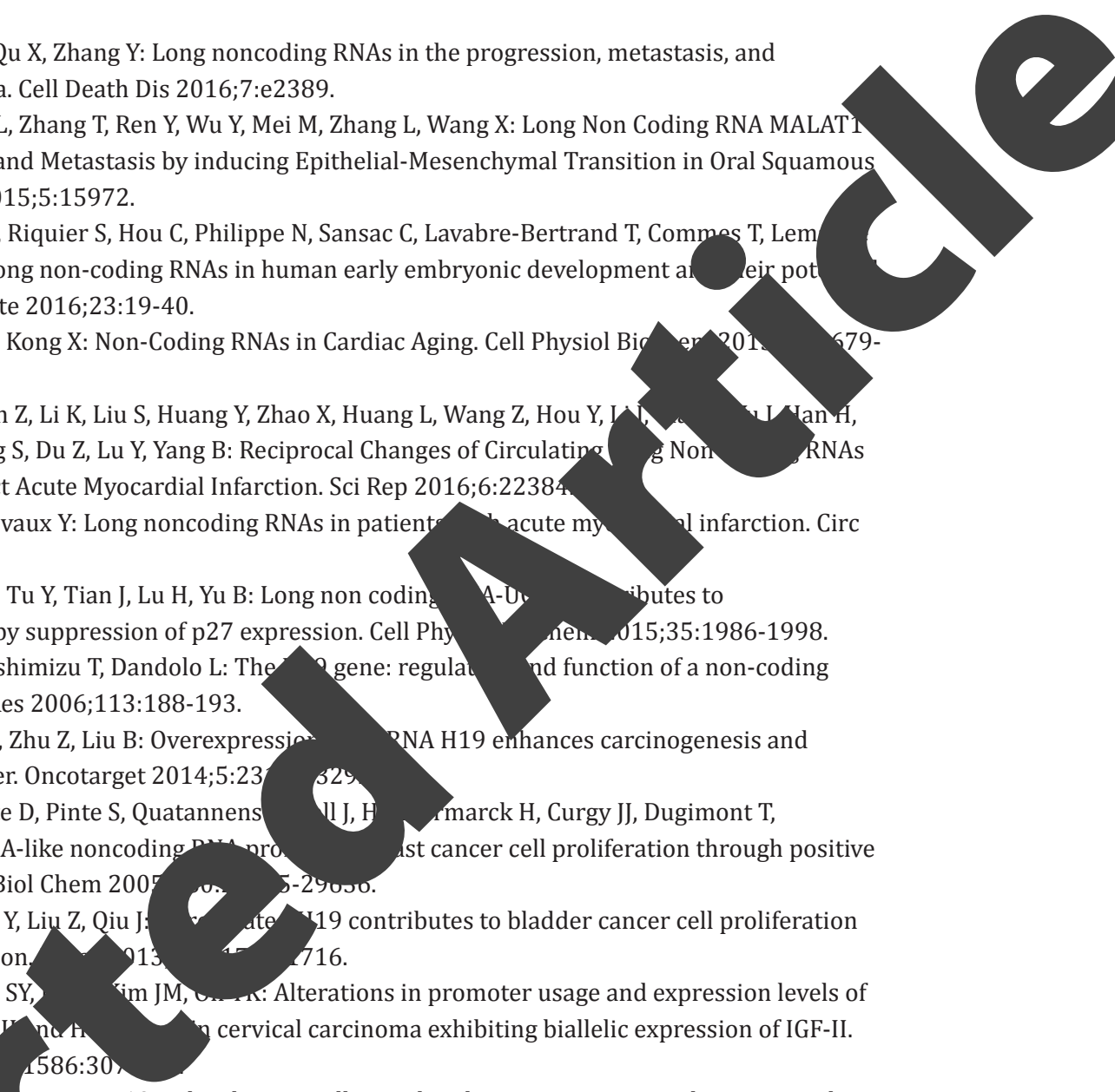
smooth muscle cells afte

att RF 19 , a developmentally regulated gene, is reexpressed in rat vascular Invest 1994; 93:355-360.

-21 Hao Y, Crensb Yton 1, wewcomb E, Tycko B: Tumour-suppressor activity of H19 RNA. Nature 1993;365:7

22 Livak $\mathrm{K}$ chmi nalysis of relative gene expression data using real-time quantitative PCR and the 2(-D elta thod. Methods 2001;25:402-408.

2 Shi Y, Luan W, Wang P, Tao T, Zhang J, Qian J, Liu N, You Y: Long non-coding RNA H19 promotes Coma pasion by deriving miR-675 PLoS One 2014;9:e86295.

L, Tjan Wang F, Zhang Z, Du C, Xie X, Kornmann M, Yang Y: The long noncoding RNA H19 promotes eration via E2F-1 in pancreatic ductal adenocarcinoma. Cancer Biol Ther 2016;17:1051-1061. Yany 1, Bi J, Xue X, Zheng L, Zhi K, Hua J, Fang G: Up-regulated long non-coding RNA H19 contributes to roliferation of gastric cancer cells. Febs j 2012;279:3159-3165. Boon RA, Dimmeler S: MicroRNAs in myocardial infarction. Nat Rev Cardiol 2015;12:135-142.

Yang L, Song S, Lv H: MicroRNA-322 protects hypoxia-induced apoptosis in cardiomyocytes via BDNF gene. Am J Transl Res 2016;8:2812-2819.

28 Ke ZP, Xu P, Shi Y, Gao AM: MicroRNA-93 inhibits ischemia-reperfusion induced cardiomyocyte apoptosis by targeting PTEN. Oncotarget 2016; 7:28796-28805.

29 Fan ZX, Yang J: The role of microRNAs in regulating myocardial ischemia reperfusion injury. Saudi Med J 2015;36:787-793.

-30 Qu Y, Wu J, Chen D, Zhao F, Liu J, Yang C, Wei D, Ferriero DM, Mu D: MiR-139-5p inhibits HGTD-P and regulates neuronal apoptosis induced by hypoxia-ischemia in neonatal rats. Neurobiol Dis 2014;63:184193. 


\section{Cellular Physiology and Biochemistry \\ Cell Physiol Biochem 2017;44:857-869 \\ \begin{tabular}{l|l}
\hline DOI: $10.1159 / 000485354$ & (c) 2017 The Author(s). Published by S. Karger AG, Basel
\end{tabular}}

Gong et al.: Role of LncRNA H19 in Hypoxia-Induced Myocardial Injury

-31 Xie C, Han Y, Liu Y, Han L, Liu J: miRNA-124 down-regulates SOX8 expression and suppresses cell proliferation in non-small cell lung cancer. Int J Clin Exp Pathol 2014;7:7518-7526.

32 Zhang S, Zhu C, Zhu L, Liu H, Liu S, Zhao N, Wu J, Huang X, Zhang Y, Jin J, Ji T, Ding X: Oncogenicity of the transcription factor SOX8 in hepatocellular carcinoma. Med Oncol 2014;31:918.

-33 Bell KM, Western PS, Sinclair AH: SOX8 expression during chick embryogenesis. Mech Dev 2000;94:257260.

34 Montero JA, Giron B, Arrechedera H, Cheng YC, Scotting P, Chimal-Monroy J, Garcia-Porrero JA, Hurle JM: Expression of Sox8, Sox 9 and Sox10 in the developing valves and autonomic nerves of the embryonic he Mech Dev 2002;118:199-202.

-35 Li C, Tian J, Li G, Jiang W, Xing Y, Hou J, Zhu H, Xu H, Zhang G, Liu Z, Ye Z: Asperosaponin VI myocytes from hypoxia-induced apoptosis via activation of the PI3K/Akt and CREB pathways Pharmacol 2010;649:100-107.

- 36 Lin KH, Kuo WW, Jiang AZ, Pai P, Lin JY, Chen WK, Day CH, Shen CY, Padma VV, Huang Tetramethylpyrazine Ameliorated Hypoxia-Induced Myocardial Cell Apoptosis via p38 and IGFBP3/BNIP3 Inhibition to Upregulate PI3K/Akt Survival Signaling. Cell 2015;36:334-344.

-37 Xiao J, Zhu X, Kang B, Xu J, Wu L, Hong J, Zhang Y, Ni X, Wang Z: Hyd Sulfide A tes Myocardial Hypoxia-Reoxygenation Injury by Inhibiting Autophagy via mTC 2015;37:2444-2453.

-38 Chen XQ Wu SH, Zhou Y, Tang YR: Lipoxin A4-induced heme oxygen hypoxia/reoxygenation injury via p38 MAPK activat and Nrf2/ARE
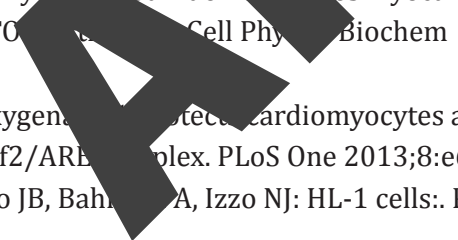
rec, ardiomyocytes against

-39 Claycomb WC, Lanson NA, Stallworth BS, Egeland Db_ rpio JB, Bah Natl Acad Sci U S A 1998;95:2979-2984.

40 Park WJ, Oh JG: SERCA2a: a prime target for modul contractility during heart failure. BMB Rep 2013;46:237-243. lex. PLoS One 2013;8:e67120. A, Izzo NJ: HL-1 cells:. Proc
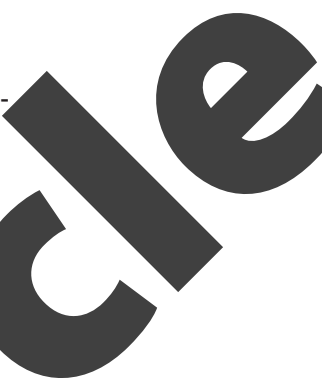
, 